\title{
THE TYRANNY OF ABSTRACTIONS
}

\author{
By William P. D. Wightman*
}

ON 4 January 1970 a new law of nature was formulated in the words 'Improvement means deterioration'. Following the usual custom, it is named after its enunciator 'Hutber's law'. The fact that it was published in the Sunday telegraph may explain why it has not yet passed into the literature of the history of science. Since it may not always have been true, it may be the first of what Whitehead was prepared to call 'epochal laws'; Whitehead himself did not exclude the possibility that all natural laws are epochal laws, that is, characteristic of a particular cosmic epoch. Just as the minds of men are broadened with the process of the suns so discrepancies of epsilon order of magnitude built into the accepted laws may not be monotonically convergent but conceal a more complex secular trend. A crude parallel would be the supposed parabolic form of the elliptic orbits of comets.

The historical epochs are of course disproportionally smaller, so the application of the epochal concept falls well within recorded time. Leaving aside the cyclical possibility of the Great Year when, it was supposed, all the great celestial luminaries would return to precisely the same positions as those occupied at the time of the observation, so that history would repeat itself precisely, we do not have to look very far back for an epoch when the ruling idea, but not the term, of 'Improvement' meant return to a Golden Age of Wisdom. Several members of our Society have revealed the persistence of this myth through the Renaissance down to, of all people, Isaac Newton'-the 'last of the Magi', as Lord Keynes characterized him. During this latter epoch the word Improvement, if it was used at all, was not applied to the retrogressive ideology then persisting in some quarters. But here a little and there a littleperhaps mainly in agriculture, where it seemed to have a clear concrete application - the identification of improvement with novelty was coming to be discernible by the beginning of the seventeenth century when the young Francis Bacon expressed the notion in language with strong overtones of the passing cosmic attitudes. ${ }^{2}$ It became prominent a little later in the concern of the recently founded Royal Society for cider apples and timber. And later still, after a confused uproar strangely named the

* 112 Rutten Lane, Yarnton, Oxford OX 5 ILR

'See, for example, J. E. McGuire and P. M. Rattansi, 'Newton and the pipes of Pan', Notes and records of the Royal Society of London, xxi (1966), $108-43$.

2 Bacon De sapientia veterum (London, 1609 ).

THE BRITISH JOURNAL FOR THE HISTORY OF SCIENCE VOL. 6 NO. 23 (1973) 
Age of Reason, 3 the idea of progress became a crusade in the early nineteenth century.

Doubting voices have long been audible: J. B. Bury from the point of view of the professional historian, 4 Peter Drucker's End of economic man (1939), Aldous Huxley's Brave new world (1932) and the still more appalling Ape and essence (1949), and perhaps, most widely known of all, Orwell's 1984 (1949). But Patrick Hutber was, with a slight qualification, the first to enunciate it in negative terms reminiscent of Sir Edmund Whittaker's three postulates of impotence. 5 The slight qualification is that Hutber's law is a precise application in the field of finance and public services of Wightman's more general law recognized by its author for at least a decade. It has never been published because it has been known and largely ignored since Man became articulate. Lucretius expressed the physical aspect in the words: 'Nature replenishes one thing out of another and does not suffer anything to be begotten before she has been recruited by the death of some other.' ${ }^{6}$ In an epoch driven towards despair by the domination of the cash-nexus Wightman's law takes the form: 'Everything must be paid for'; or, in the chant of the Pop and Hippy culture, 'Nothing is for free'.

It would have been more modest of the author to have called it the Wightman-Fichte Law since, contrary to a rather common and not unnatural misunderstanding, Fichte was the original enunciator of what passes for Hegelian dialectic: Every thesis generates an antithesis, and it is the business of the philosopher to transcend this by a synthesis that becomes the thesis of higher order and so, like the little fleas, ad infinitum. Hegel, of whom I shall have to speak at some length later, introduced into this form of dialectic a modification of fundamental importance.

I must admit frankly that the title of this address is a flag of convenience; my discourse is related to the title in a manner similar to that in which among the avant-garde (or are they already the ci-devant?) a montage of a couple of golden syrup tins and a tangle of barbed wire bears the legend Young woman undressing. In each case the cognoscenti will doubtless discover a wealth of hidden meaning. However, I would not have it assumed that I am not taking my task seriously. What I have to say in relation to my title-'The tyranny of abstractions'-is certainly no laughing matter. The tyranny of abstractions is a real tyranny. The bloodiest and most devastating wars have not been fought over a piece of territory or a trade route, at least not ostensibly, but over abstractions. This is not necessarily to condemn those who fought in them, who in most cases suffered in all sincerity for a cause which they believed to be

${ }_{3}$ I am currently engaged on a critical essay in which the basis of this judgment is discussed. 4 In his The idea of progress (London, 1920).

$5 \mathrm{E}$. T. Whittaker, 'Some disputed questions in the philosophy of the physical sciences', Proceedings of the Royal Society of Edinburgh, Section A, lxi (1942), 160-75.

6 Lucretius, De rerum natura, i. 11. 262-4. 
more precious than life itself. But it is necessary to reveal abstractions for what in most cases they are: Idols of the human mind. I discovered long ago that hate, however 'righteous', solves nothing; but age has reluctantly convinced me that love without reason, as Sir Karl Popper put it, 'opens the way for those who rule by hate'. Five hundred years earlier Erasmus wrote 'Precatio potior . . . scientia non minus necessaria tamen'.7 For Erasmus 'scientia' of course meant something like 'exact knowledge', which is a necessary factor in 'reason'. But what is 'reason' without the critical scrutiny of the abstractions with which it deals? Twenty years ago, perhaps even ten years ago, I should have regarded lugubrious moralizings such as these to be wholly out of place in a discourse to this society. Later I shall attempt to justify their inclusion; but, since that will involve a further discussion of some ideas that are perhaps unfamiliar, I ask your indulgence to postpone this attempt until we have considered some examples, as we might say, nearer home.

G. M. Young claimed that it was Maitland who first 'revealed that the essential matter of history is not what happened but what people thought and said about it'. No better example of this can be given than that intriguing abstraction known as 'The Renaissance'. One of the earliest enunciations of this abstraction was that of Iohannes Reuchlin in the dedication of his $D e$ arte cabbalistica to Leo $\mathrm{X}$ written in 15 $^{\mathrm{I}}$ :

Italian philosophy was killed innumerable years ago by the deafening barking of sophists, buried for so long in shadows and deep night until by favour of the gods the Sun of every kind of good learning, the most famous Lorenzo de' Medici, your father and offspring of great Cosimo, rose up as ruler of the state of Florence.

This was repeated in rather less elegant Latin thirty years later by the famous scholar-physician, Jean Fernel, in a dedication to Henry II of France. ${ }^{8}$ The language of Reuchlin is that of myth; philosophy had been 'killed', 'buried in shadows and long night' (Fernel's estimate of this 'night' was I,200 years) until the 'Sun of learning' had arisen and so on. A scholar of Reuchlin's range and learning could not conceivably have believed in the literal truth of this high-flown nonsense. But by I 548 and in France Fernel may already have begun to take it seriously. Nearly fifty years ago, when I started to study the history of science, the myth had become an established historical datum, though, unknown to me, voices such as Pierre Duhem's were beginning to 'bark' again, as Reuchlin might have said. I have risked taxing your patience with this case-history, probably well known to most of you, partly because it is one in which I am most at home and partly just because it is so well known. I know of none that illustrates so well Adam Smith's observation that 'Mankind have had at all times a strong propensity to realize their own

7 Erasmus, Enchiridion militis christiani (1503).

8 Fernel, De abditis rerum causis libri duo (Paris, 1548). 
abstractions'.9 By 'realize' Smith meant, I take it, 'to make a reality of' what Whitehead calls the 'fallacy of misplaced concrete'. ro

This brings me to the other term in my title, 'Tyranny'. I must at once make my position clear before considering other less glaring abstractions. Since the whole content of science in the modern English sense of the term is made up of the relations subsisting in a highly formalized set of abstractions-called 'atoms', 'genes', Rana temporaria, oxygen, velocity, and so on ad infinitum-we have to face the dilemma 'no abstractions, no science'. In the case of history the position is not quite so clear; the Renaissance is certainly an abstraction and, when properly subdued, no tyrant but perhaps indispensable. But whether you call Reuchlin and Leo X abstractions or not depends upon your metaphysics. To hear this term applied to themselves may send a frisson through those historians who regard philosophy as the foolish talk of idle old men to ignorant youths. But whether they like it or not, to deny the relevance of metaphysics to history is to adopt a metaphysical posture. Whether such historians thus become members of that paradoxical class of all classes that are not members of themselves I will not attempt to determine, since such a last straw would probably call forth a sign from the Senior Vice-President to the stewards to conduct me from the chamber. Fortunately the decision, if a decision is possible, appears to me irrelevant.

As many of you know, though I try to be a historian, I am fundamentally a philosophical animal. In case some of you for the first time have discovered that the Society has been harbouring a serpent in its bosom I will quote a sentence from a letter I received from one of those younger members $I$ have been privileged to associate with in what Whitehead called the 'imaginative consideration of learning'.

I had a good chuckle [my young associate wrote] over your paper on quantization, and yet I take its serious points about the history and philosophy of science. There is a lesson in it for me, who am trying to combine the two, that history has its own integrity and cannot be regarded as simply the empirical wing of the subject.

This succinctly expresses my opening remarks to a university group dedicated to the philosophy of science at a critical time for the future of our endeavour.

In my amphibious role I now return to the explication of the term 'Tyranny', calling to my aid this time a great historian, Lord Acton; and I shall pay him the honour he so seldom receives of correct quotation. 'Power', he wrote to Bishop Creighton, 'tends to corrupt and absolute power corrupts absolutely. Great men are nearly always bad.' In this he was perhaps echoing the famous orientalist Sir William Jones, who nearly

- Smith, Essays on philosophical subjects, ed. J. Black and J. Hutton (London, I 795).

1o See especially A. N. Whitehead, Science and the modern world (Cambridge, 1926), p. 82, but the whole of Chapter 3 leads up to the notion. See also Chapter 4 (p. 85). 
a century earlier wrote to Lord Althorpe: 'My opinion is that power should always be distrusted in whatever hands it is placed.' I I think it was Sir William Hamilton (often foolishly called 'the bad philosopher' to distinguish him from a certainly greater man, the mathematician William Rowan Hamilton) who said: 'Words are the fortresses of thought'; that is, I take it, instruments either to display, or just as likely to conceal, power. Of course, he must have been referring to abstract words thus invested with power. Acton's judgment, then, expresses my attitude to the 'Tyranny' of abstractions. History and, alas, our own time abound in examples of men of good will who have been allowed to become tyrants through inadequate means of setting limits to their power. Abstractions, I have claimed, are the whole of science and, with one literally vital exception, if my metaphysics is well founded, the whole of history. For me the only ultimate realities in history are individual human beings. To attempt to wriggle out of historical responsibility, it is no use invoking abstract 'forces'; to invoke 'historical inevitability' is to my mind a kind of blasphemy. But these 'vital exceptions', as I have called them, exclude the possibility of history being solely concerned with abstractions; hence, pace Bury, history can never be a science in the English sense of this word. However, it can and ought to be a Wissenschaft, even, to use Edmund Husserl's criterion of philosophy, eine strenge Wissenschaft. If this criterion is accepted, then every term must be examined for latent vagueness or ambiguity. My credo that the only ultimate realities in history are individual human beings begs many questions of which the worst is of course 'real'. Here Plato is my guide, and derivatively Whitehead, though the latter explicates the word in terms of Descartes's res vera. ${ }^{12}$ In the Sophist ${ }^{13}$ it is the Stranger from Elea who proposes, as a mark to distinguish real things, that they are nothing but power-power either to

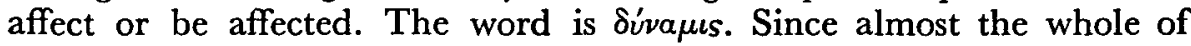
modern physics separates Whitehead even from Descartes it is not surprising that his notion of a res vera goes beyond that of Descartes in a fundamental way - a way of immense significance for history, since for him the reality of a thing is constituted by its 'becoming'. The emphasis on becoming as against permanence is of course the reverse of Plato'swhich illustrates the danger of attributing Party Membership to anyone who applies the Party Line. My acceptance of Plato's 'mark of the real' as one of the most illuminating insights in the history of thought does not turn me into a Platonist.

I came across an illuminating example of this recently when engaged

"Letter from Jones to Althorpe, 5 October 1782 , in John Shore (Baron Teignmouth), Memoirs of the life, writings and correspondence of Sir William Jones (new edn., 2 vols., London, 1835).

in Whitehead, Process and reality (Cambridge, 1929), p. 55 and passim.

${ }^{13}$ Sophist, 247 E. See F. M. Cornford, Plato's theory of knowledge (London, 1935), p. 234-8 for a discussion of the context. 
on deepening my scanty knowledge of that transitional period when predominantly 'Renaissance' modes of thought were giving way to the more characteristically 'scientific' style of the seventeenth century. The emergence of 'science' at that time is commonly associated with the displacement of the 'qualitative' Aristotelian by the quantitative Platonic Weltanschauung. Being temperamentally agin those who are agin the government (which is not by any means the same thing as being for the government), I have been largely interested in trying to break through the tyranny of this over-simplified abstraction. After all, the Greeks both before and after Aristotle were quite good mathematicians; probably the high-water mark of medieval natural philosophy was the ingenious mathematical abstraction of the followers of Thomas Bradwardine in Oxford and of that even more wide-ranging genius, Nicole Oresme, in Paris. The almost single-handed attempt of Nicholas of Cues was ingeniously, if not very convincingly, mathematical and fundamentally Platonic-or at least Neoplatonic-throughout. Cusanus died in 1464 at Todi, where the more professional mathematician Paolo dal Pozzo, commonly known as Toscanelli, witnessed his will. In Aberdeen I spent about ten years looking for the beginning of characteristically modern science during the subsequent century or so; and I am still looking. I found countless intriguing near misses; but, despite mathematics and Plato, my search was unsuccessful. Though I am far from wishing to replace one abstractive tyranny by another, I suggest to you that a new attitude to experiment was at least as important as Plato (or even Archimedes) and mathematics ueberhaupt.

Now one of the half dozen leading exponents of this new attitude was William Gilbert, whose De magnete was described as physiologia nova, plurimis $\mathcal{E}$ argumentis $\mathcal{E}$ experimentis demonstrata. His book was, I think, wholly devoid of mathematics and contains no more quantification than Harvey's De motu cordis, namely the recognition, also stressed by Francis Bacon, of the importance of the less and the more in rooting natural philosophy in nature, that is, the material world. All this is well known; but what was not well known to me is Gilbert's anomalous stance in regard to the confrontation between Plato and Aristotle. ${ }^{14}$ He does indeed praise Plato and censure Aristotle, but for what? Because Aristotle, contrary, as Gilbert says, to Plato, Orpheus, Hermes, and Zoroaster, denied anima to any but the celestial regions. By anima Gilbert must have meant l'amor che move il sole e l'altre stelli, since the three grades of $\psi v x \dot{\eta}$ (usually translated anima) play an essential part in Aristotle's natural philosophy. Gilbert does in fact liken the anima that is his concern to the human soul dum organico corpore alligatur. This censure of Aristotle for not allowing the presence of 'souls', in the Neoplatonic sense, in natural objects as distinguished from 'things divine' comes strangely

14 Gilbert, De magnete (London, 160o), Book V, chapter 12. 
from one of the principal founders of the so-called 'scientific revolution'; it was a demarcation that Harvey had to insist upon in his 'second disquisition' addressed to the younger Riolan. ${ }^{15}$ It only goes to show that too stark a decision between the rival abstractions of Platonism and Aristotelianism can miss reality. Nevertheless, in the long view Gilbert may have been on the right tack; at any rate Leibniz, Hegel, Whitehead, and I were compelled to adopt not altogether dissimilar views.

The other alleged condition for the emergence of 'modern' sciencethe application of the most powerful mathematics that the age providedwas unquestionably necessary. Mathematics provides, if not the language, at least the syntax of a language in which the most fruitful abstractions derived from phenomena can be expressed and developed. But, precisely because of its immense power to generate further abstractions, it must be subject to checks and balances, as Newton and many of his great contemporaries realized. To claim that mathematics was not only the necessary but also the sufficient condition for understanding nature is to endow a supremely beautiful instrument with the power of tyranny. Absolute power corrupts absolutely. Or, in terms proper to the Computer Age: Garbage in, garbage out.

The one Renaissance thinker who pinpointed this was Giordano Bruno. ${ }^{16} \mathrm{I}$ should be the last to extol Bruno as a 'scientist'; but when, following Aristotle, he insisted that mathematical objects are human artefacts, he was dead on target. How could such abstract universals having no exemplification in nature provide an understanding of nature? A similar argument was presented nearly two centuries later by a more temperate and orderly thinker than Bruno, the historian Giambattista Vico. ${ }^{77}$ Nor was his a lone voice. About thirty years later still, and probably in ignorance of Vico, another and at that time far more influential voice sounded the same alarm, though it was not backed by the same argument. The source of the following citation will at once be recognized by those more familiar with the period than I am: 'Les abstractions mathématiques nous en facilitent la connaissance; mais elles ne sont utiles qu'autant qu'on ne s'y borne pas.' As an example of the danger of restricting oneself to mathematical abstractions, the writer goes on to regret that 'le corps humain, cette machine si compliquée, a été traité par nos médecins algébristes comme le serait la machine la plus simple ou la plus facile à décomposer'. This was not the complaint of a disgruntled

15 In the Everyman edition of An anatomical disquisition on the motion of the heart $\mathbb{E}$ blood in animals (London, 1923), the relevant passage is on p. 142.

${ }_{16} \mathrm{His}$ dogmatic hostility to mathematics as mere passamento dei pazzi ingegnosi (La cena de le ceneri [London, $15^{8} 4$ ], third dialogue) appears passim in his works. In the De immenso et innumerabilibus (III, vi) the Platonic source of the above argument provides another example of the danger referred to in note 14. See P.-H. Michel, La cosmologie de Giordano Bruno (Paris, 1962), p. 223 and passim.

${ }_{17}$ See A. Corsano, 'Vico and mathematics', in G. Tagliacozzo and H. V. White (eds.), Giambattista Vico. An international symposium (Baltimore, 1969), pp. 425-37. 
physician but of one of the leading analysts of the age, or indeed of any age, Jean le Rond d'Alembert, in the 'Discours préliminaire' of the Encyclopédie, first published in $175^{1.18}$

But it is time I fulfilled my promise to justify a predominantly 'philosophical' address. My justification is the growing tendency for the majority of historians of science to claim that the subject of their studies has both an internal and an external aspect. Many, including myself, welcome this as a valuable distinction but would maintain that it is nevertheless possible to do work of the highest importance treated from either of these points of view. In demanding (every 'hopeful' wish has nowadays to be submitted as a 'demand') the mutual involvement of history and philosophy of science, I have similarly insisted on their individual integrity so far as research is concerned. But-and it is a big 'but'-I am at one with those who claim that an uncritical procedure within one framework of ideas may lead to pseudo-history. It is all a matter of respecting the relevance of the two abstractions from the total human situation. However, there are some members who claim that every problem must be treated both inwardly and outwardly. I suppose they would claim that to try to interpret Faraday's attitude to natural philosophy merely from a study of his publications, letters, and notebooks would place a distorting restriction on the study. I 83 I was indeed the year of his conception of electromagnetic induction in terms of what he called the electrotonic state; but the high significance of this date is lost unless it is recalled that in the following year was passed the first Reform Bill. The nature of this correlation has not yet been studied, so far as I am aware. I make no charge for the suggestion that here is a topic on which one of the pupils of the Conjoint Inner and Outer Front in search of a Ph.D. might exercise his ingenuity.

Quite recently, however, I was startled to see that one of our members, from whom many of us have learnt much, was putting forward a third view: not either-or, not both-and, but neither. 'If it [sc. science]', he writes, 'is considered as a socially organized and supported intellectual enterprise engaged in understanding and controlling nature its history should demonstrate a synthesis of social and intellectual elements from which the fruitless distinction between externalist and internalist historiographies would be excluded.' 19 His hypothesis, with some reservations, I accept;

Is 'Discours préliminaire des éditeurs', in the Encyclopedie, ou dictionnaire raisonné des sciences, des arts et des metiers, i (Paris, 175I), pp. vi and vii. A more detailed study of d'Alembert reveals an inconsistency of this judgment with his life-long aim to 'prove' that 'geometry' (to which he believed he had 'reduced' mechanics) alone gives certain knowledge. I can but suggest on the one hand that he was hoping to persuade as large a public as possible to invest in the Encyclopedie, and on the other that the inconsistency is only apparent. Medicine was not, nor ever could be, 'exact'; but to force upon it the deductive, abstract method of mathematics was a bar to the attainment of such a degree of 'knowledge' as was possible. See the excellent biography, Jean d'Alembert. Science and the Enlightenment (Oxford, 1970) by Thomas L. Hankins, who, however, does not refer to this matter specifically.

19 J. B. Morrell, 'The University of Edinburgh in the late eighteenth century: its scientific eminence and academic structure', Isis, lxii (1971), $15^{8}$. 
his conclusion I deny, for reasons that I think I have already sufficiently stated. But the argument has at least a superficial resemblance to what Karl Marx in a different context described as 'standing Hegel on his head'. Thus the traditional thesis that 'the history of science should be studied in complete abstraction from all other circumstances' properly generated the antithesis 'that it must be regarded simply as a derivative from socioeconomic history', and is resolved in the above synthesis by assuming that any such distinction is 'fruitless'. To discuss the matter further within this framework would itself be fruitless, since Marx, in company with most of the so-called British Hegelians-the Scots were somewhat better guides than the English-overlooked the essential modification that Hegel introduced into the Fichtean dialectic. But since 'Hegel' still turns up as a dirty word in science-historical writing I must first swat the two major myths attaching to him: swatting myths, as John Fulton once wrote to me in another connexion, is as much fun as swatting moths.

First, then, for Hegel's alleged ukase against the possibility of discovering any more than five planets within the known solar system. The facts, available for more than I50 years, are as follows. In his Habilitation dissertation at Jena ( $180 \mathrm{I}$ ) Hegel did speak rather scornfully of contemporary efforts to discover a planet in the 'gap' revealed by the so-called 'law' of Bode relating the regularity of interplanetary distances. This was a foolish piece of dogmatism in the face of the wholly unexpected discovery of the external planet Uranus in 1781 . In 1801 the planetoid Ceres was discovered within the 'gap'. Tardily indeed, but unreservedly, Hegel subsequently wrote: 'Was ich in einer früherer Dissertation hierüber versucht habe kann ich nicht mehr für befriedigend ansehen.'

The second myth is that Hegel was wholly out of touch with the great scientific advances made during his lifetime. In fact, as $\mathrm{Dr}$ Michael Petry has recently demonstrated in a massive work of great erudition, ${ }^{20}$ it is doubtful whether anyone during Hegel's lifetime, except William Whewell towards the end of it, had such an accurate and encyclopaedic knowledge of the facts, pseudo-facts, and hypotheses of the contemporary sciences. When he went wrong it was more likely to be because he was too closely in touch and relying upon the accounts provided by contemporary scientists. When he took upon himself the task of criticism he often showed himself far ahead of the contemporary dogmatism. One example will have to suffice. In almost excessive opposition to the Schelling-Oken Naturphilosophie ${ }^{21}$ Hegel proclaimed his own aim to develop what Aristotle had begun in the Physics, which he rightly saw was much nearer to the philosophy of nature than was the physics of his own (Hegel's) day. I shall quote two expressions of this attitude:

${ }^{20}$ Hegel's philosophy of nature, ed. and trans. M. J. Petry (3 vols., London, 1970).

${ }^{2 x}$ For an illustration of this tradition see, for example, Lorenz Oken, Elements of physiophilosophy, trans. A. Tulk (London, 1847). 
Physics no longer confronts nature as an objective observer but sees itself as an actor in this interplay between man and nature. The scientific method by analysing, explaining and classifying has become conscious of its human limitations which arise out of the fact that by its intervention physics alters and refashions the object of its investigation. In other words method and object can no longer be separated.

\section{The second passage is as follows:}

The first thing to be noticed about the distinction between physics and philosophy of nature [not of course Naturphilosophie] is ... that they are not so widely separated as they might seem to be at first . . empirical physics contains much more thought than it will either realize or admit ... Physics and the philosophy of nature are therefore to be distinguished not as perception and thought but merely by the nature and manner of their thought. Both are a thinking cognition of nature.

Some of you will doubtless have noticed that $I$ have been cheating. There is a noticeable inconsistency between the frank admission in the first of the fusion of method and object, and the accusation in the second of a reluctance on the part of physics to admit this. The discrepancy is hardly surprising since the first passage was written rather more than a century after Hegel wrote the second;22 its author was in fact Werner Heisenberg. ${ }^{23}$ Nevertheless I have altered only one word, putting 'physics' in place of Heisenberg's 'science'-a permissible substitution in view of the fact that, when Hegel was writing, physics was far more advanced relative to the other sciences than when Heisenberg made his submission. ${ }^{24}$ It was in fact the day of those superb phenomenalistic pseudo-Newtonians, A. M. Ampère (c. I 822) and Joseph Fourier (c. I810, but fully developed in the Théorie analytique de la chaleur [1822]). What an astonishingly prophetic soul was Hegel's!

Having, as I hope, established Hegel's claim to a hearing, I return to examine his relevance to the question of internal and external. Whereas the Fichtean synthesis obliterates the contradiction between thesis and its generated antithesis, the Hegelian dialectic retains it at a higher level. The German word is aufheben. I am but an indifferent German scholar but I confess to finding 'aufheben' much more comprehensible than the fabricated term 'sublate' by which it is usually rendered in English translations.

The basic Hegelian triad arises out of the nature of Pure Beingwhat remains after abstraction even more drastic than that which yielded

22 Hegel's philosophy of nature, i. 193.

${ }_{23}$ Quoted by W. H. Auden in $A$ certain world (London, 1970), p. 333.

24 The English word 'science' in its present connotation was in fact first used in 1796 by Richard Kirwan; see the passage quoted in the $O E D$ entry on 'science': 'Previous to the year I 780 mineralogy though tolerably well understood as an art could scarce be deemed a science.' Much the same might have been said about chemistry, botany, geology, for example, but mechanics, optics, sound, static electricity, and (to a lesser extent) heat were firmly founded as departments of the science of physics. By the time Hegel was writing, only chemistry, and that but partially, could compete with physics. 
Descartes's 'extension'-the ultimate 'being' devoid of any distinguishing characteristic. How, asks Hegel, does this differ from its anti-thesis Non-being? Not at all; and yet we speak, as we believe clearly and distinctly of each. The synthesis for Hegel (but not, of course, for Descartes) is in 'Becoming'. In this, as in much more, Hegel is nearer to Aristotle than to Plato; although of all great philosophers, the nearest to Hegel (though, through his very understandable inability to read Hegel, he seems to have been unaware of this proximity!) was Whitehead, whose most apposite resolution of this dilemma was: 'There is no Nature at an instant.' Hegel might have preferred the more general form, 'There is no History at an instant', since for him Nature and History are both developments of Geist, the former in space, the latter in time.25 In another of its aspects history is (as for Bolingbroke) 'philosophy teaching by examples'; and philosophy . . . well, before I risk sinking in the bottomless bog of Hegel's philosophy, I feel constrained to repeat what I have often said before: that there is no more tyrannical-or, if you will, treacherous - abstraction than the instant. Endowed by Leibniz with absolute power as the protean differential, it was brought within the conventions of the law and order governing the Never-Never Land of pure mathematics by Weierstrass and others. But as an ignorant layman, I have hazarded the guess--various aspects of it indeed supported by the authority of great names-that this wholly non-empirical fabrication of the human mind, which has been made the ultimate basis of natural science, has been responsible for the generation of more paradoxes, whether in the implications of the quantum theory or in the so-called 'problem' of induction, than any other. The uncritical assumption in economic science of 'equilibrium' (whose actual occurrence would be the mark of what political economists are trying to avoid, namely stagnation) as the basis of the most sophisticated mathematical models plays a large part in the financial and industrial chaos characteristic of a 'scientific age'. 26 By the time the truck load of statistics has been accumulated and transferred to the hopper, they are inevitably obsolete. Something more akin to the thermodynamics of open systems and systems-analysis might provide the model, but the statistics involve human beings whose behaviour has little to do with 'instants'.

In what Sir Karl Popper has most admirably called 'our infinite ignorance', such abstractions are of course indispensable; but to treat them as sacrosanct, as we too often do, is to court disaster. 'Absolute

${ }_{35} \mathrm{Hegel}$, Reason in history. A general introduction to the philosophy of history, ed. and trans. R. S. Hartmann (Indianapolis, 1953), p. 87.

${ }^{26}$ Cf. Joan Robinson's comment: 'An equilibrium system, by its very nature, is cut off from reality. It is useless to interpret history in terms of it and illegitimate to appeal to history for evidence to support it. All it can do is to display the logical relations generated by its assumption'; from her Collecled economic papers, (3 vols., Oxford, I95I-65), iii. 19. See further Stafford Beer, 'The world, the flesh and the metal: the prerogatives of systems', Nature, ccv (1965), 223$3 \mathrm{I}$; the whole article might be regarded as an attack on the 'futility of abstraction'. 
true ["true" mark you!] and mathematical time' was an indispensable servant but a tyrannical master; distance-simultaneity had to go the same way. Josiah Willard Gibbs had to replace the pseudo-empirical temperature ('pseudo' in those physical contexts where it operates merely as a statistical abstraction-a temperature of one molecule is meaningless) by the undefined primitive non-empirical 'entropy'. The time may come when in the analysis of human experience we may have to stand Gibbs on his head, replacing the non-existent 'instant' by an empirical concept combining the extensional 'drop' of William James ${ }^{27}$ with the experienced vectoriality of Leibniz and Whitehead, trailing clouds of glory from the past and big with the future. There is a sense in which both the past and the future are more real than the present.

For of such is history. Without the 'future' (not necessarily 'progress'), history is indeed a tale told by an idiot full of sound and fury but signifying literally nothing. No one, or so we mostly believe, has experienced the events of the future, yet its 'lure' in Whitehead's compelling phrase is certainly no less 'real' than the past. Hegel's almost poetic insight into this aspect of time, uncharacteristically expressed in intelligible phrases, was for me a sufficient reward for the struggle through the bog of verbiage in which he chose to isolate his very numerous flowers of understanding. ${ }^{28}$

Fortunately there is no time to deal with the technicalities of Hegel's argument. But the conclusion-that the ultimate reality is geistlichis one that, as contemporary historians, we cannot afford to ignore. By 'contemporary historians' I mean contemporary historians in the sense that all history is contemporary history-a thoroughly Hegelian view, I suspect. To believe otherwise is to live an abstraction. We must indeed make the literally superhuman effort to project ourselves back into the world of our actors, be they Archimedes, Nicholas of Cues, Newton, or even Max Planck. But we can do so, if at all, only in the light of our own contemporary experience. Inevitably we know more of Newton's world than the narrow compass of Woolsthorpe, Cambridge, and London afforded him: External influences, like cosmic rays, were pouring in upon him; to assess their influence on the man himself and his work is the struggle and the sense of exaltation that make history both a science and an art.

For contemporary historians to ignore the so-called Marxian interpretation of history would be to hide one's head deep in the sand. I refer to it as 'Marxian' since this avoids the question-begging epithet 'materialist'. I hope that in my ignorance I do him no injustice in saying that

27 'Either your experience is of no content or it is a perceptible amount of content or change. Your acquaintance with reality grows literally by buds or drops of perception' (William James; quoted in Whitehead, op. cit. [12], p. 94). James comments: 'Intellectually [i.e. by abstraction] and on reflection you can divide these into components, but as immediately given they come totally or not at all.'

${ }_{28}$ See Hegel's philosophy of nature, i. 229 f., but especially the 'Addition' on p. 23 I. 
Marx was not very good at history, rather worse at economics, ${ }^{29}$ but the founder of a very great secular religion (if the Hegelian contradiction be permitted) based on profound sociological insight and learning. The critical scientific mind of Friedrich Engels greatly increased the significance of Marx's rather naïve sketch, from which the cruder over-simplifications were subsequently removed by George Plekhanov in a manifesto $3^{\circ}$ that might almost be called 'The tyranny of abstractions'. Marx's alleged 'upending' of Hegel was his belief that the latter's subsumption of reality in the dialectical unfolding of the geistlich Idea provided an admirable model for his own system if only you replaced the geistlich Idea by Matter -hence the descriptive term 'dialectical materialism'. I have had to employ the word 'geistlich' since both 'Mind' and 'Spirit' commonly used in translations have both overtones and undertones that may distort or restrict the understanding of Hegel's intention.

The point I want especially to make-probably well known to all, but like Wightman's law hardly ever taken account of-is that, as generally applied, both Geist and Matter are tyrannical and baseless abstractions. Hegel not only recognized this but even insisted on it. In his Geist matter was not denied: It was aufgehoben; that is, when recognized as a well-founded abstraction, it was essential for the interpretation of certain highly important aspects of experience. Following the traditional philosophical custom, Hegel called it a universal abstracted from the concrete universal he called Idea, of which Geist in its more usual connotation was also an essential abstraction.3r

I have found no such admission in Marxian dialectics, though Engels was indeed ahead of the contemporary natural philosophers in enlarging the concept of 'inanimate brute matter' to make possible the indubitable emergence of life and mental operations. Consequently I am compelled to reverse the popular and loosely worded judgment. For me the uncompromising empiricist was Hegel; the metaphysical idealist, Marx.

I have dealt with controversial issues touching on matters of faith and party strife. If the endeavour of our Society is to treat the history of science as a significant abstraction from human history, this is a risk that

${ }^{29}$ This is what I said 'in my haste'. I now recognize that in respect of economics my remark was far too sweeping. I am again indebted to Mrs Robinson, who, in 'What remains of Marxism' (Robinson, op. cit. [26], iii. 158-66) argues persuasively that comparison with the neo-classical (pre-Keynesian) equilibrium theory is 'highly favourable to Marx'. But in 'prophesying' the collapse of capitalistic society on the analogy of the past, Marx was mixing somewhat dubious history with political ideology. Nevertheless, once more to plunder Mrs Robinson ('Marxism, religion and science', op. cit. p. I55): 'You have nothing to lose but [sc. under continuing capitalistic expansion] the prospect of a suburban house and a motor car would not have been much of a slogan.'

30 Plekhanov, The materialist conception of history (New York, 1940).

31 To pick out lapidary phrases from Hegel's works is nctoriously to invite misunderstanding; but the Zusatz on pp. 18-20 of A. V. Miller's recent Hegel's philosophy of mind (Oxford, 1971) is as free from danger of misunderstanding as most. A 'symipathetic' refutation of materialism will be found on p. 34 . 
must from time to time be run. I confess to a feeling of surprised admiration when our joint meeting with the Past and Present Society on 'The patronage of science in the nineteenth century' (14 April 1972) was conducted in a civilized manner increasingly rare in the 'confrontations' beloved of the 'media'. Incidentally, these labels-Left, Right, Divisive, Establishment, and the like-when used out of context, are among the uglier of popular abstractions, confused almost to the point of meaninglessness. When Elizabeth I occupied the throne of England, anyone whose views were disliked was called a Jesuit. In my young days 'Bolshevist' was the most favoured equivalent. Now in the reign of Elizabeth II of Great Britain and Northern Ireland (some historians seem to have overlooked the fact that England ceased to be a sovereign state in 1707), the most effective method of disposing of an argument and of its proponent is held to be that of labelling them 'Middle Class'. A historian who aims at being a 'neutral' succeeds only in being a bore. I may have attained the latter state but not as the consequence of the former aim. My aim was set when many years ago I came across the claim that the greatest contribution of the Greeks was not their mathematics, their sculpture, or their tragedy, but their recognition that civilization depends on the $\mu \epsilon \nu$ and the $\delta \epsilon$ : 'On the one hand, and on the other.' This was what, 'once upon a time', the academic life was about. Truth and Beauty, like Peace, may be one and indivisible and as such unattainable in the world of Man. But if swollen by Pride, blinded by Prejudice, a slave to Sense, devoid of Sensibility, and knowing no Persuasion but the shoutdown, the Trahison des clercs should gain its ends, it will be the greatest betrayal in history.

All this notwithstanding, when in my solitude I see, or seem to see, the lights going out not only, as in 1914, over Europe, but over the whole world I draw hope from the recollection of those occasions that your suffrages have made possible to a degree I could not otherwise have hoped for-occasions of the 'imaginative consideration of learning' with young men and (an advantage I have had over Socrates!) young women 'of a generous spirit, and all those in whom beauty dwells'. 